NOTE

\title{
Stable isotope food web studies: a case for standardized sample treatment
}

\author{
Ute Jacob*, Katja Mintenbeck, Thomas Brey, Rainer Knust, Kerstin Beyer
}

Alfred Wegener Institute for Polar and Marine Research, PO Box 120161, 27515 Bremerhaven, Germany

\begin{abstract}
Enrichment of the stable isotopes ${ }^{13} \mathrm{C}$ and ${ }^{15} \mathrm{~N}$ across trophic levels is a commonly used tool in studies on organic matter flow and food webs. However, there is still no accepted standard for pre-analysis sample preparation. Thus, potential methodological bias in single studies may hamper comparability and scalability of data from different sources. Sample $\mathrm{CaCO}_{3}$ content introduces a positive bias in $\delta^{13} \mathrm{C}$ measurements and a negative bias in $\delta^{15} \mathrm{~N}$ measurements. The acidification of samples to remove inorganic carbonate significantly reduces both $\delta^{13} \mathrm{C}$ and $\delta^{15} \mathrm{~N}$. As a standard procedure we recommend (1) acidifying samples with as little hydrochloric acid ( $\mathrm{HCl}$ ) as possible using the drop-by-drop technique, and (2) restraining from rinsing after $\mathrm{HCl}$ application.
\end{abstract}

KEY WORDS: Isotope signatures $\cdot$ Carbonates $\cdot$ Sample acidification

Resale or republication not permitted without written consent of the publisher

\section{INTRODUCTION}

Metabolic processing of ingested organic matter causes isotopic fractionation of ${ }^{13} \mathrm{C}:{ }^{12} \mathrm{C}$ and ${ }^{15} \mathrm{~N}:{ }^{14} \mathrm{~N}$ stable isotope pairs. Therefore, the stable isotope ratios of $\delta^{13} \mathrm{C}$ and $\delta^{15} \mathrm{~N}$ are proxies of the trophic distance of an organism from the origin of the corresponding food chain. Although the underlying physiological, biochemical and biophysical processes are not yet fully understood (Ponsard \& Averbuch 1999), enrichment of the stable isotopes ${ }^{13} \mathrm{C}$ and ${ }^{15} \mathrm{~N}$ across trophic levels is a commonly used tool in studies on organic matter flow and food webs in aquatic and terrestrial ecosystems. On average, $\delta^{13} \mathrm{C}$ and $\delta^{15} \mathrm{~N}$ increase by 0.5 to 1 and 2.8 to $3.4 \%$, respectively, from one trophic level to the next (e.g. Minagawa \& Wada 1984, Peterson \& Fry 1987, Michener \& Schell 1994). Early trophic stable isotope studies relied on $\delta^{13} \mathrm{C}$ only (Fry 1984, Fry \& Sherr 1984). The finding that $\delta^{13} \mathrm{C}$ correlates with tissue fat content, whereas $\delta^{15} \mathrm{~N}$ does not, led to the parallel application of both isotope ratios in more recent studies (e.g. Fry 1988, Rau et al. 1991, 1992). Although the magnitude of variation in $\delta^{13} \mathrm{C}$ fractionation is the major source of error in quantitative stable isotope models (Vander Zanden \& Rasmussen 2001), $\delta^{13} \mathrm{C}$ is still used as it serves as a valuable carbon source tracer (e.g. Lesage et al. 2001). The major methodological question regarding the simultaneous measurement of $\delta^{13} \mathrm{C}$ and $\delta^{15} \mathrm{~N}$ is whether the removal of inorganic carbonate $\left(\mathrm{CaCO}_{3}\right.$, for instance in red algae, cnidarians, bryozoans, mollusks, echinoderms) from the sample will bias tissue stable isotope ratios (Fry 1988, Cloern et al. 2002). Carbon incorporated in tissue and in carbonate are of different origin and hence differ in $\delta^{13} C_{i}$ therefore, carbonate must be removed by acidification prior to mass spectrometry (Fry 1988, Rau et al. 1991, Cloern et al. 2002). It remains unclear, however, whether tissue isotopic ratios are affected by acidification or not; there is contradictory evidence regarding $\delta^{15} \mathrm{~N}$, whereas no significant impact on $\delta^{13} \mathrm{C}$ has been reported (Bunn et al. 1995, Bosley \& Wainright 1999, Pinnegar \& Polunin 1999). Our study, based on 193 samples from 29 species (11 major taxa), analyzes (1) how sample $\mathrm{CaCO}_{3}$ content affects stable isotope ratios, and (2) whether $\delta^{13} \mathrm{C}$ and $\delta^{15} \mathrm{~N}$ are affected by sample acidification. 


\section{MATERIALS AND METHODS}

A total of 92 invertebrate samples (18 species among crustaceans, bryozoans, brachiopods, cephalopods, sponges, cnidarians, echiurids, polychetes, pantopods and echinoderms) and 101 fish samples (11 species) were collected for stable isotope analysis from fauna sampled along the Scotia Arc and the Antarctic Peninsula. Small organisms were analyzed whole, whereas in macro- and megafaunal specimens only body wall pieces or muscle tissue samples were used. All samples were kept frozen at $-30^{\circ} \mathrm{C}$ until further analysis. Samples were lyophilisated for $24 \mathrm{~h}$ in a Finn-Aqua Lyovac GT2E and then ground to a fine powder. Each sample was split in half: one part was acidified to remove $\mathrm{CaCO}_{3}$ in accordance with Fry (1988) and Cloern et al. (2002) by adding $1 \mathrm{~mol} \mathrm{l}^{-1}$ hydrochloric acid ( $\mathrm{HCl}$ ) drop-by-drop until no more $\mathrm{CO}_{2}$ was released, re-dried at $60^{\circ} \mathrm{C}$ without rinsing to minimize loss of DOM (dissolved organic matter) and ground again; the other half did not receive any further treatment. Stable isotope analysis was conducted with an isotope-ratio mass spectrometer (Thermo/Finnigan Delta plus, GeoBioCenter). Experimental precision (based on standard deviation of replicates of a peptone standard) was $\leq 0.15 \%$ for carbon and nitrogen.

A paired Student's $t$-test was used to evaluate whether stable isotope ratios differed between 'crude' and acidified samples. Sample $\mathrm{CaCO}_{3}$ content had not been determined; hence, we used a $\mathrm{CaCO}_{3}$ proxy to analyze the effect of $\mathrm{CaCO}_{3}$ on stable isotope ratios:

$$
\text { carbonate proxy }=\frac{[\mathrm{C}: \mathrm{N}]_{\text {crude }}}{[\mathrm{C}: \mathrm{N}]_{\text {acid }}}-1
$$

where $[\mathrm{C}: \mathrm{N}]_{\text {crude }}$ is the $\mathrm{C}: \mathrm{N}$ ratio of a non-acidified sample and $[\mathrm{C}: \mathrm{N}]_{\text {acid }}$ is the $\mathrm{C}: \mathrm{N}$ ratio of an acidified sample. This proxy should be linearly related to sample $\mathrm{CaCO}_{3}$ content, provided that tissue C:N is independent of sample $\mathrm{CaCO}_{3}$.

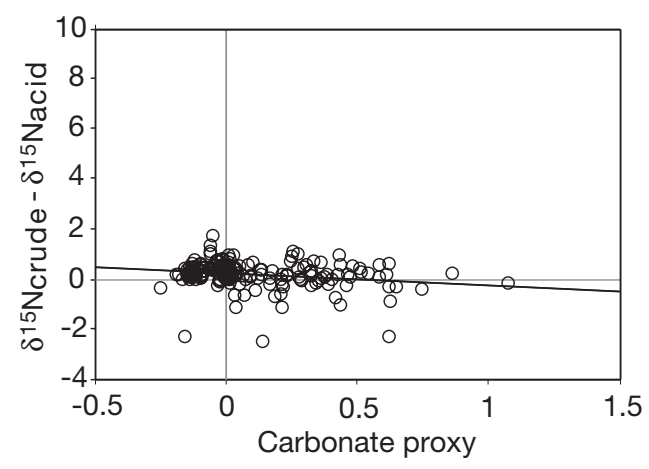

Fig. 1. Effect of sample $\mathrm{CaCO}_{3}$ content on the difference in $\delta^{15} \mathrm{~N}$ between acidified and non-acidified samples. Sample $\mathrm{CaCO}_{3}$ is approximated by the carbonate proxy $[\mathrm{C}: \mathrm{N}]_{\text {crude }} /$ $[\mathrm{C}: \mathrm{N}]_{\text {acid. }}$ Significant linear relation: $y=0.248-0.486 \times x$, $\mathrm{r}^{2}=0.047, \mathrm{p}=0.0033, \mathrm{~N}=193$

\section{RESULTS AND DISCUSSION}

Surprisingly, a number of samples showed negative carbonate proxy values (Figs. 1 \& 2). Analysis of presumably $\mathrm{CaCO}_{3}$ free samples (fish and polychaete tissue) showed that, on average, acidification decreased tissue $\mathrm{N}$ content $\left(\mathrm{N}_{\text {acid }}=-0.15 \mathrm{~N}_{\text {crude }}\right)$ proportionally more than tissue $\mathrm{C}$ content $\left(\mathrm{C}_{\text {acid }}=-0.11 \mathrm{C}_{\text {crude }}\right)$, thus causing higher $\mathrm{C} / \mathrm{N}$ ratios in acidified samples. There is no need to correct the carbonate proxy value for this effect, as we assume it to be independent of sample $\mathrm{CaCO}_{3}$ content.

$\delta^{15} \mathrm{~N}_{\text {crude }}-\delta^{15} \mathrm{~N}_{\text {acid }}$ was negatively related to sample $\mathrm{CaCO}_{3}$ content (linear regression: $\mathrm{df}=192, \mathrm{p}=0.0033$, Fig. 1), whereas tissue $\delta^{13} \mathrm{C}_{\text {crude }}-\delta^{13} \mathrm{C}_{\text {acid }}$ was positively related to sample $\mathrm{CaCO}_{3}$ content (linear regression: $\mathrm{df}=192, \mathrm{p}<0.0001$, Fig. 2). In samples containing no $\mathrm{CaCO}_{3}$ (defined by carbonate proxy $\leq 0.03$ ), acid treatment showed a significant negative effect on both $\delta^{15} \mathrm{~N}$ (paired $t$-test: mean difference $=0.320 \%, \mathrm{SE}=0.037$, $\mathrm{df}=115, \mathrm{p}=0.0001)$ and $\delta^{13} \mathrm{C}$ (paired $t$-test: mean difference $=0.117 \%, \mathrm{SE}=0.044, \mathrm{df}=115, \mathrm{p}=0.0081$ ).

The ongoing discussion of whether samples should be treated with $\mathrm{HCl}$, how this treatment should be carried out, and what effect the treatment may have on isotope ratios as well as the contradictory findings (Bunn et al. 1995, Bosley \& Wainright 1999, Pinnegar \& Polunin 1999, McCutchan et al. 2003) shows that there is an urgent need for sample treatment standardization.

Regarding $\delta^{13} \mathrm{C}$, our results indicate the expected positive relation between the acidification effect on $\delta^{13} \mathrm{C}$ and sample $\mathrm{CaCO}_{3}$ content (Fig. 2). The bias caused by $\mathrm{CaCO}_{3}$ was in the range of the distance between subsequent trophic levels (0.5 to $1.0 \%$ ) at carbonate proxy values as low as 0.08 (Fig. 2). Regarding $\delta^{15} \mathrm{~N}$, this is the first study that demonstrates a significant negative, albeit weak, effect of sample $\mathrm{CaCO}_{3}$ on tissue $\delta^{15} \mathrm{~N}$ (Fig. 1), the mechanism of which, however, remains unclear.

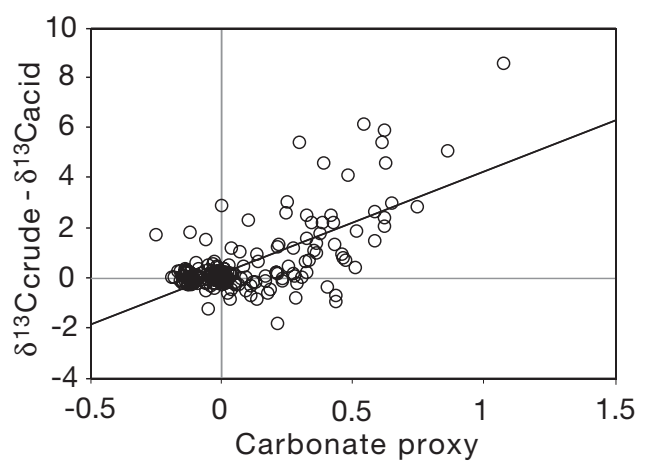

Fig. 2. Effect of sample $\mathrm{CaCO}_{3}$ content on the difference in $\delta^{13} \mathrm{C}$ between acidified and non-acidified samples. Sample $\mathrm{CaCO}_{3}$ is approximated by the carbonate proxy $[\mathrm{C}: \mathrm{N}]_{\text {crude }} /$ $[\mathrm{C}: \mathrm{N}]_{\text {acid }}$. Significant linear relation: $y=0.181+4.08 \times x$, $\mathrm{r}^{2}=0.449, \mathrm{p}=0.0001, \mathrm{~N}=193$ 
The analysis of samples containing no $\mathrm{CaCO}_{3}$ showed that acidification caused a significant (average $=0.117 \%$ o) decrease in $\delta^{13} \mathrm{C}$. This deviation is (1) about $16 \%$ of the average shift of 0.5 to $1 \%$ from one trophic level to the next, (2) within the $\delta^{13} \mathrm{C}$ variability observed in one trophic compartment (e.g. Rau et al. 1991, Vander Zanden \& Rasmussen 2001, Cloern et al. 2002), and (3) in the range of measurement precision $(\leq 0.15 \%) . \delta^{15} \mathrm{~N}$ was also negatively affected (average $=$ $0.320 \%$ ), but to a much lesser extent regarding the average shift of 2.8 to $3.4 \%$ from one trophic level to the next as well as $\delta^{15} \mathrm{~N}$ variability within one trophic compartment (e.g. Adams \& Sterner 2000, Dunton 2001, Iken et al. 2001, Nyssen et al. 2002). The shift was, however, distinctly above measurement precision $(\leq 0.15 \%$ o). Our findings support Bosley \& Wainright's (1999) view that the way and extent to which $\delta^{15} \mathrm{~N}$ is affected by acidification depends on the methods applied, mainly on the rinsing of the acidified sample with distilled water. Our drop-by-drop acidification technique without subsequent rinsing appeared to produce, on average, little bias in $\delta^{15} \mathrm{~N}$ and low intersample variability in bias (Figs. $1 \& 2$ ). The 3 outliers in Fig. 1 were most likely to be caused by mistakes during sample processing.

\section{CONCLUSION}

Tissue samples must be acidified in order to make stable isotope data comparable across taxa with varying $\mathrm{CaCO}_{3}$ content. Data from non-acidified but carbonate-free samples can be made comparable to data from acidified samples by the corresponding correction factors for $\delta^{13} \mathrm{C}\left(-0.117 \%\right.$ o) and $\delta^{15} \mathrm{~N}(-0.320 \%)$. It remains to be seen, however, whether the factors found here are also valid for non-Antarctic ecosystems.

For future food web studies using $\delta^{13} \mathrm{C}$ and $\delta^{15} \mathrm{~N}$ simultaneously, we recommend the following procedure to standardize sample treatment: (1) Acidify samples prior to stable isotope analysis by careful application of as little $\mathrm{HCl}$ as possible. Apply $1 \mathrm{~mol} \mathrm{l}^{-1} \mathrm{HCl}$ drop-bydrop until no further $\mathrm{CO}_{2}$ development is visible.

(2) Dry acidified samples directly, do not rinse with water after acidification.

\section{LITERATURE CITED}

Adams TS, Sterner RW (2000) The effect of dietary nitrogen content on trophic level ${ }^{15} \mathrm{~N}$ enrichment. Limnol Oceanogr 45:601-607

Bosley KL, Wainright SC (1999) Effects of preservatives and acidification on the stable isotope ratios $\left({ }^{15} \mathrm{~N}:{ }^{14} \mathrm{~N},{ }^{13} \mathrm{C}:{ }^{12} \mathrm{C}\right)$

Editorial responsibility: Otto Kinne (Editor-in-Chief), Oldendorf/Luhe, Germany of two species of marine animals. Can J Fish Aquat Sci $56: 2181-2185$

Bunn SE, Loneragan NR, Kempster MA (1995) Effects of acid washing on stable isotope ratios of $\mathrm{C}$ and $\mathrm{N}$ in penaeid shrimp and seagrass: implications for food-web studies using multiple stable isotopes. Limnol Oceanogr 40:622-625

Cloern, JE, Canuel EA, Harris D (2002) Stable carbon and nitrogen isotope composition of aquatic and terrestrial plants of the San Francisco Bay estuarine system. Limnol Oceanogr 47:713-729

Dunton $\mathrm{KH}$ (2001) $\delta^{15} \mathrm{~N}$ and $\delta^{13} \mathrm{C}$ measurements of Antarctic Peninsula fauna: trophic relationships and assimilation of benthic seaweeds. Am Zool 41:99-112

Fry B (1984) ${ }^{13} \mathrm{C} /{ }^{12} \mathrm{C}$ ratios and the trophic importance of algae in Florida Syringodium filiforme seagrass meadows. Mar Biol 79:11-19

Fry B (1988) Food web structure on Georges Bank from stable C, N, and S isotopic compositions. Limnol Oceanogr 33: $1182-1190$

Fry B, Sherr EB (1984) $\delta^{13} \mathrm{C}$ measurements as indicators of carbon flow in marine and freshwater ecosystems. Cont Mar Sci 27:13-47

Iken K, Brey T, Wand U, Voigt J, Junghans P (2001) Food web structure of the benthic community at the Porcupine Abyssal Plain (NE Atlantic): a stable isotope analysis. Prog Oceanogr 50:383-405

Lesage V, Hammill MO, Kovacs KM (2001) Marine mammals and the community structure of the Estuary and Gulf of St Lawrence, Canada: evidence from stable isotope analysis. Mar Ecol Prog Ser 210:203-221

McCutchan JH Jr, Lewis WM Jr, Kendall C, McGrath CC (2003) Variation in trophic shift for stable isotope ratios of carbon, nitrogen and sulfur. Oikos 102:378-390

Michener RH, Schell DM (1994) Stable isotope ratios as tracers in marine aquatic food webs. In: Lajtha K, Michener RH (eds) Stable isotopes in ecology and environmental science. Blackwell Scientific, Oxford, p 138-158

Minagawa M, Wada E (1984) Stepwise enrichment of $\delta^{15} \mathrm{~N}$ along food chains: further evidence and the relation between $\delta^{15} \mathrm{~N}$ and animal age. Geochim Cosmochim Acta 48:1135-1140

Nyssen F, Brey T, Lepoint G, Bouquegneau JM, De Broyer C, Dauby P (2002) A stable isotope approach to the western Weddell Sea trophic web: focus on benthic amphipods. Polar Biol 25:280-287

Peterson BJ, Fry B (1987) Stable isotopes in ecosystem studies. Annu Rev Ecol Syst 18:293-320

Pinnegar JK, Polunin NVC (1999) Differential fractionations of $\delta^{13} \mathrm{C}$ and $\delta^{15} \mathrm{~N}$ among fish tissues: implications for the study of trophic interactions. Funct Ecol 13:225-231

Ponsard S, Averbuch P (1999) Should growing and adult animals fed on the same diet show different delta ${ }^{15} \mathrm{~N}$ values? Rapid Commun Mass Spectrom 13:1305-1310

Rau GH, Hopkins TL, Torres JJ $(1991){ }^{15} \mathrm{~N}:{ }^{14} \mathrm{~N}$ and ${ }^{13} \mathrm{C}:{ }^{12} \mathrm{C}$ in Weddell Sea invertebrates: implications for feeding diversity. Mar Ecol Prog Ser 77:1-6

Rau GH, Ainley DG, Bengston JL, Torres JJ, Hopkins TL (1992) ${ }^{15} \mathrm{~N}:{ }^{14} \mathrm{~N}$ and ${ }^{13} \mathrm{C}:{ }^{12} \mathrm{C}$ in Weddell Sea birds, seals and fish: implications for diet and trophic structure. Mar Ecol Prog Ser 84:1-8

Vander Zanden MJ, Rasmussen JB (2001) Variation in $\delta^{15} \mathrm{~N}$ and $\delta^{13} \mathrm{C}$ trophic fractionation: implications for aquatic food web studies. Limnol Oceanogr 46:2061-2066

Submitted: March 30, 2004; Accepted: December 14, 2004

Proofs received from author(s): February 1, 2005 